\title{
Miyazawa Kenji: Interpretation of his Literature in the Present Japan ${ }^{1}$
}

\author{
Nagisa MORITOKI ŠKOF*
}

\begin{abstract}
This paper seeks an answer to the question of why Kenji Miyazawa is attracting people's attention now more than ever, with particular focus on Miyazawa's view on Buddhism and nature, as expressed in his literature, by considering its value in contemporary Japan. This paper takes three features as examples: "the true happiness", changing phenomena, and interaction between human beings and nature; and it concludes that Miyazawa's messages support people in present-day Japan and assure them that they are on the right path in the long flow of the universe's historical timeline.
\end{abstract}

Keywords: Buddhism, nature, literature, Japan, interaction

\section{Izvleček}

Članek poskuša najti odgovor na vprašanje, zakaj je delo Kenjija Miyazawe še vedno priljubljeno na Japonskem, danes bolj kot kadarkoli, članek osredotoča na Miyazawov pogled na budizem in naravo, kakor se odražata v njegovi književnosti, in poskuša oceniti njen pomen $\mathrm{v}$ sodobni Japonski. Za primer si vzame tri značilnosti iz njegovih del: »resnično srečo«, vedno spreminjajoče se pojave in medsebojni odnos med človekom in naravo, ter zaključi, da sporočilnost Miyazawovega dela nudi oporo ljudem na Japonskem tudi $\mathrm{v}$ današnjem času in jim zagotavlja, da je pot, po kateri grejo, pravilna pot znotraj dolgega toka vesoljske zgodovine.

Ključne besede: Budizem, narava, literatura, Japonska, medsebojno vplivanje

\footnotetext{
${ }^{1}$ This article is based on these two lectures about MIYAZAWA Kenji on "Teden UL" (Open day of the University of Ljubljana), December 6, 2012 and "Pozor, Znanje na Cesti!" (Warning, Knowledge is on the street!), December 19, 2012. I thank the University of Ljubljana and my colleague at the Department of Asian and African Studies for giving me these precious opportunities to carry out the lectures for various audiences.

* Nagisa MORITOKI ŠKOF, PhD, Assistant Professor, Department of Asian and African Studies, Faculty of Arts, University of Ljubljana.

nagisa.moritoki@guest.arnes.si
} 


\section{Kenji Miyazawa - an Increasingly Attractive Author}

Kenji Miyazawa lived from 1896 to 1933 in the Tōhoku region, the northeast area of Japan. Though only a few of his works were published during his short life of 37 years, he left many works in poetry and "juvenile" literature, which were published with the help of his literary fellows after his death. Now, about 100 years later, Miyazawa is still attracting much attention with his unique literary style, language use and motifs. Some remarkable works were published recentlyMiyazawa's complete works in 2009, several of his films in the 1990s, and one film in 2012. Public readings have also been held more frequently than before.

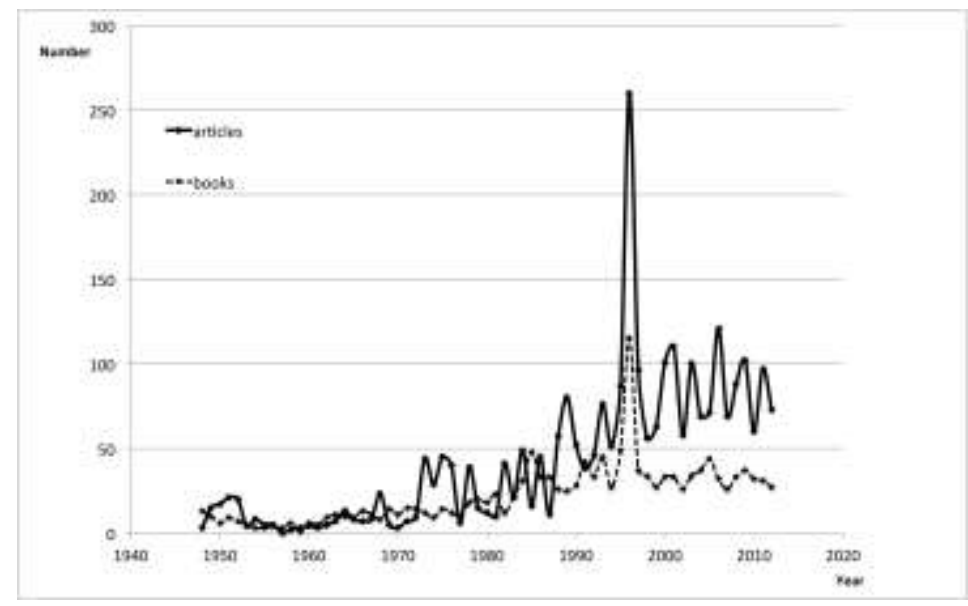

Fig. 1: The number of titles that include the name of "Kenji Miyazawa"

Figure 1 shows the number of titles that include the name of "Kenji Miyazawa" either in books or articles in academic journals throughout Japan, based on the CiNii database (Scholarly and Academic Information Navigator) ${ }^{2}$. The dotted line shows that the number of books published has slowly but constantly been increasing throughout the period from 1948 to 2012. Both the numbers of books and academic articles exponentially increased in 1996. It was the year that marked the $100^{\text {th }}$ anniversary of Miyazawa's birth which is assumed to have caused the increase in people's and also academic researchers' interest. Among them, some philosophers left eminent essays, such as Tetsuzō Tanikawa (1950, 1951, 1953), Takeshi Umehara (1985) and Takaaki Yoshimoto (1989). Miyazawa is a

\footnotetext{
${ }^{2}$ http://ci.nii.ac.jp/en. Books written by Kenji Miyazawa (complete works, reprinted editions and so on) are also counted.
} 
remarkable person whose ideas still motivate various philosophers and researchers. The number of academic articles also shows a gradual rise despite the fact that their instant increases and decreases throughout the whole of the period. In addition to the increasing number of the academic journals in the last few decades, it is remarkable that Miyazawa is still attracting researchers' interest in a variety of fields, such as literature and linguistics, psychology, city planning, and even environmentology (Numata 1997, 86).

Based on the facts above, the question of why Miyazawa is retaining people's attention now more than ever, is something that goes without saying. This paper seeks an answer to the question, focusing on Miyazawa's views on Buddhism and nature that are expressed in his literature, and considering its value in contemporary Japan.

\section{Historical Background and Buddhism}

Miyazawa was born in 1896 in Hanamaki city, Iwate prefecture, in northeast Japan. He was born just two months after the Meiji Sanriku Offshore Earthquake, and an accompanying tsunami that devastated the coastline, just $40 \mathrm{~km}$ away from his birth city, which caused more than 20,000 deaths (Yoshimura 2004, 171). Only a few days after his birth, another big earthquake took place, causing even more damage to this northeast region of Japan.

The region is known as the rice-producing region of Japan. However, in the years around Miyazawa's birth, low summer temperatures often reduced the crops and hit farmers' budgets. Consequently, mass famine and starvation spread and reached their peaks during the years between 1902 and 1906, and in 1913, and again between 1931 and 1935. The situation was so grave that farmers' families often had to sell or abandon their children, which was a great blow to the whole Japanese society (National Agriculture). During that period highly motivated farmers led agricultural improvement and the movement was later taken over by government and administrative agencies.

Miyazawa was one such motivated leader. A higher education school to which Miyazawa went to (Morioka Higher School for Agriculture and Forestry, now Iwate University) was the first governmental higher educational school for agriculture and forestry in Japan working with intent to improve Japanese agriculture (Menda 2012, 150). 
While many farmers in the north-eastern area have difficulties supporting their families, Miyazawa was never short of money. His family ran a successful pawnshop in Hanamaki city, and as the eldest son in the family he was expected to overtake the family business. His father earned money with items from poor farmer's property, and his family lived an elegant life from such profits. Miyazawa as a child was well aware of the neighbouring farmers' poverty, and it is said that this trauma may have influenced his adult life (Nakano 1984, 166; Kumata 1994, 12).

Buddhism is also thought to have strongly influenced Miyazawa's life. In order to understand his devotion to Buddhism and its influence on Miyazawa's literature, let us take a brief look at the background of Buddhism around Miyazawa's life time. It was in 1968, nearly 30 years before Miyazawa's birth, when the Tokugawa shogunate turned over its power to the Emperor and a new democratic government was formed. This is known as the Meiji Ishin 明治維新 (Meiji Restoration). Until then, Buddhism and Shintoism were gradually intertwining. Meiji government enforced a series of laws to separate Buddhism from Shintoism with the purpose of concentrating the power of the new government with more relevance between Shintoism and Emperor. This act deeply damaged the status of Buddhism.

In this situation, oppressed Buddhists actively recuperated its force. Local people often carried out Buddhist lectures and study courses, inviting priests and intellectuals as lecturers. This was also common practice in the area where Miyazawa was born, and Buddhists made sympathetic visits to the people suffering from cold weather and consequential poverty (Kurihara 2011, 95). One of such Buddhist devotees and activists was Miyazawa's father, Masajirō. Besides his business as a pawnbroker, he worked for the Jödo Shinsh $\bar{u}$ 浄土真宗 (True Pure Land sect) and often attended such lectures accompanied by his family (Okaya 1996, 1; Okaya 1999, 39).

True Pure Land sect is a Buddhism sect founded by a priest Shinran in the $12^{\text {th }}$ century. Its doctrine is to focus on Amida. True Pure Land sect preaches that people are saved and lead to the Jōdo 浄土 (Pure Land) where they are released from worries and pains; they devote to its chanting phrase "Nam Amida Butsu" for this sake. True Pure Land sect also teaches that people should accumulate 'good things' in order to become a bodhisattva - a person who is to be with people, and spontaneously represents them the right way to attain a sense of sentient being. 
Miyazawa's frequent visits to local Buddhist lectures and contacts with close family members, especially women from his childhood, such as his mother and aunts, are considered to have caused him feeling of sympathy, compassion, and the earnest wish to be of service to suffering people (Kurihara 2011, 90).

In adulthood, religion was often the cause of Miyazawa's getting into bitter arguments with his father. He entered another sect of Buddhism, the Nichirensh $\bar{u}$ 日蓮宗 (Nichiren sect), and tried to persuade his father to convert to Nichiren sect. Nichiren sect was founded by a priest Nichiren in the $13^{\text {th }}$ century. Nichiren told people that the highest teaching can be found in the Lotus Sutra and told them to chant the phrase "Nam myōhō renge kyō." Although both True Pure Land sect and Nichiren sect are Buddhist sects, they have differences in their doctrines. One of the main differences is that, while True Pure Land sect tells people they will be relieved in the Pure Land after their death, Nichiren sect teaches that they will be relieved in this world only if they have lived their lives according to the Lotus Sutra (Sueki 2000: 151). This was an important argument for Miyazawa. He thought that poor people should be relieved in this world before their deaths, and the doctrine of Nichiren sect encouraged him. There are also other teachings of Nichiren sect:

All people, even animals, plants and nature, have Buddhahood by nature

The chanting of the phrase 'Nam myōhō renge kyō' leads you to the state of the Bodhisattva to awaked to the truth.

In order to be a Bodhisattva you should practice thinking of others as of yourself, and devote yourself to help others.

Miyazawa's literature strongly reflects such teachings. One of the examples that Nichiren sect was important for Miyazawa is that the chanting phrase 'Nam myōhō renge kyo' ' was written in the end of his famous poem Amenimo Makezu (Strong in the Rain).

\section{Science and Nature}

Being called “Ishikko Ken-san”「石つこ賢さん」 (“Ken, the boy of stone”) in his childhood, he collected stones of the neighbourhood. While he was prone to illness and not good at sports, he astonished his classmates on a school excursion when he, with his exceptional endurance, reached the top of a hill earlier than anyone. 
However, his interests were not limited to stones, i.e. mineralogy, as he also explored geology, astronomy, physics and others (Numata 1997, 85) in addition to literature and music. He studied devotedly at Morioka Higher School for Agriculture and Forestry, because the opportunity to enter a higher school has once been completely denied by his father. His father wished Miyazawa to take over his business as a pawnbroker and was against Miyazawa's desire to continue his studies. Miyazawa fell ill and had to stay at home after graduating from junior high school, but after that, he was finally allowed to go on to higher school. $\mathrm{He}$ delightedly enrolled with the top score of the entrance exam of the Higher School (Chiba 2007, 192). He became a teacher at a higher school in Hanamaki city in 1921 at the age of 25 , but he earned his living this way for only a period of four years.

Though he specialized in agriculture, he took studious interest in various fields by himself. He further fastened his knowledge and studies of minerals in his adulthood. "Mineral" is often used as a metaphor for a star and other things in his late literature. Another theme in his literature is music. He would buy numerous records recommended by record companies in England because their records sold well. Due to his sense and interest in sounds, his expressions concerning sounds and dialect were very unique (Yamaori 2006, 116-22) and many onomatopoetic words were created to describe winds, cries of animals, and even glittering of stars. When he was in Tokyo he took a short course in German, and he also wrote poems in Esperanto.

Despite Miyazawa's dilemma in the gap between wealthy pawnbrokers and small farmers, and the religious opposition between Miyazawa and his father, Miyazawa's father would satisfy all of his son's needs (Numata 1997, 85). With an allowance Miyazawa could buy a lot of study books and records, even though he earned money for just four years. Miyazawa often asked for money and his father would never begrudge sending money to his first son. By sending him money, his father would feel as though he had some authority over Miyazawa. On the other hand, Miyazawa viewed himself as an honourable person because, though supplied with unscrupulous founds, he was engaged in the honourable work of helping the weakest farmers. Anyhow, it was an ironical circulation of money: Miyazawa's father as a pawnbroker squeezing it from farmers, and Miyazawa financially being supported by his father's money and spending it on goods that he believed would improve farmers' lives although not releasing them from poverty. 


\section{Buddhism and Science in Miyazawa's Literature}

This section examines how Miyazawa's background, described in the previous section, is reflected in his literature. Three of the main features are taken as examples: “Hontō no shiawase” ほんとうのしあわせ (“the true happiness”), changing phenomena, and interaction between human beings and nature.

\subsection{The True Happiness}

The first representative feature pointed out in his literature is the sense of "the true happiness." It immediately raises a question about what "the true happiness" is. It is suggested to be a concept towards which one has to live and to devote himself, though Miyazawa did not leave any clear definition or concrete explanation of it. There is an example expression that involves "the true happiness."

I would never stop asking myself about which way to take-a religious way or a scientific way. The former one is to think that something like cosmic volition would lead all creatures to "the true happiness," the latter one is to think of it as being accidental and blind. I dare say it should be the former. I persist, as a pupil of a secondary school, that there are in fact many levels of sense in the universe, and that the very last level takes all lives to the extreme happiness, apart from any delusion. (Kōhon Miyazawa Kenji Zenshū) $)^{3}$

Miyazawa believed in the existence of a special force that leads our lives. Additionally, his definition of "we" includes all creatures, humans, animals, and plants, as well as things. Everything in nature exists without boundaries, such as boundaries between people of different nationalities, or boundaries between living creatures and non-living things (Kumata 1994, 11). Miyazawa blindly believed in his concept of "the true happiness" as being a dynamic force or movement, which would only lead him if he believed in its existence. It was something completely different from static substances such as $J \bar{o} d o$ or heaven. In this meaning "the true happiness" is.

He expressed "the true happiness" in one of his masterpieces, "Ginga Tetsudō no Yoru”『銀河鉄道の夜』(“Night on the Milky Way Train”), as cited below.

\footnotetext{
${ }^{3}$ This sentence is cited from the commentary in Miyazawa 1988a, 334. The original sentence is in Kōhon Miyazawa Kenji Zenshū 校本 宮澤賢治全集 (“Variorum of Miyazawa Kenji”), Vol. 13, pp. 453-54. Translation by the author of the article.
} 
Giovanni took in a deep breath.

"Campanella, it is just the two of us again. Let's go together. I don't mind burning my body hundreds of times, as the scorpion did, for everyone to reach the true happiness."

"Yeah, so do I," tears started to form in Campanella's eyes.

"But what on Earth is the true happiness?" asked Giovanni.

"I don't know," said Campanella vaguely.

$$
\text { Ginga Tetsudō no Yoru }{ }^{4} \text { (Miyazawa 1988a, 215-16) }
$$

As seen from the above conversation, the two boys did not know what "the true happiness" was. However, they did know how precious it was, and what they needed to do to attention the happiness. The two boys knew that "the true happiness" involved self-sacrifice and that they would need to make great effort to reach "the true happiness".

This self-sacrifice for the real happiness is a motif often found in Miyazawa's literature (Yamaori 2006, 127). “Gusukō Budori no Denki” 『グスコーブドリの 伝記』 (“The Biography of Gusukō Budori”) is a story of Gusukō Budori who lived in Ihatov. People in Ihatov were suffering from famine due to cold weather for several years. Budori planned, together with Dr. Kūbō and other colleagues, to make the volcano erupt so that the earth temperature would rise and people would again be able to grow rice in the warmer climate, and would, therefore, be rescued from their present situation. However, in order to make the volcano erupt, the person who would carry it out would have to sacrifice himself. Budori volunteered to do that, and succeeded to make the volcano erupt, saved the people of Ihatov.

"The true happiness" reminds us of the fact that people are relieved from hardships. Nichiren sect, which Miyazawa devoted himself to, teaches that every person can be relieved but should constantly be doing good deeds for reaching such a state. One has to practice it ascetically, for everyone around him, and not egoistically for himself. One should follow the so-called six deeds (six pāramitā), are generosity, virtuosity, and renunciation. People in Miyazawa's literature are described as religiously "good" people. This may again be based on Nichiren's teaching that everyone may possess Buddhahood by nature and can therefore become Bodhisattva, a being who may be awaken to the truth. Miyazawa included

\footnotetext{
${ }^{4}$ Shinpen Ginga Tetsudō no Yoru 新編 銀河鉄道の夜 (“New Edition: Night on the Milky Way Train”), pp. 215-16. Translation by the author of the article.
} 
characters into his literature on condition that everyone is a good person by nature, and that they do not mind doing a good deed for "the true happiness."

\subsection{Changing Phenomena}

The second feature found in Miyazawa's literature is the idea that all people and all things are constantly changing. The idea tells us that everything changes and that nothing is the same as it was before. Miyazawa pointed out that human beings are not an exception to the 'change'. His description of a human being can be found in the beginning lines of "Haru to Shura” 『春と修羅』 ("Spring and the Asura"), his only published collection of poems in his lifetime:

The phenomenon called I

Is a single blue illumination

Of a presupposed organic alternating current lamp

Haru to Shura ${ }^{5}$ (Miyazawa 1991, 19)

In this statement the human being is regarded as a changing phenomenon rather than a static substantial entity. The idea associates the dynamic concept of "the true happiness" which was described in the previous section. "The true happiness" is defined as some force or movement rather than a concrete thing. In other words, for Miyazawa, everything - humans, animals, nature, etc.-is unsubstantial and is changing over time.

Matasaburō, a boy in “Kaze no Matasaburō"『風の又三郎』(“Matasaburō, the Wind Imp"), is also described as a changing phenomenon. This is a story about village boys. Saburō was a red-haired boy who was transferred to a village school on a windy day. He perplexed other village boys with his eccentricity at first, but gradually he was accepted by the fearing but endearing village boys. However, the boys' odd friendship suddenly came to an end, and Saburō was transferred to another school on a next windy day. Boys in the village said that Saburō must have been a wind imp. Saburō was a strange boy and he was different from the others, which made it hard for him to get along with them in the beginning. However, neither he nor the village boys are ever described as bad in the story. The manner of the co-existence was changing constantly, but nobody was defined as good or bad. Their relationship is allowed to change, and Saburō and the boys

\footnotetext{
${ }^{5}$ Translation by Roger Pulvers (Miyazawa 1997).
} 
in the village affect each other. The wind is a symbol of all the changing phenomena.

The idea that all things are constantly changing is found in medieval literature as one of strong themes in Japanese literal tradition. “Hōjoki "『方丈記』written by Kamo no Chōmei in 1212, only 10 years before of Nichiren's birth, was one of such medieval works that described earthquakes, disasters and famine of the period in which the author lived. The work expresses the pitiless world. It starts as below:

The flowing river

never stops

and yet the water

never stays

the same.

Foam floats

upn the pools, scattering, reforming, never lingering long.

$H_{o ̄ j o ̄ k i}{ }^{6}$ (Kamono 1996).

In this phrase people are compared to the bubbles in the river. Bubbles appear and disappear, they come and they go. Hojjoki stresses that everything is changeable, and the same idea can later on be found in Miyazawa's literature many years later. How Hōjōki is different in is that the person in Hōjōki observes things changing but is not related to this change himself, as this literature is called "literature of resignation." He sees bubbles, lives and the world, and feels deep grief, as even nature, which seems eternal, actually changes. When a human being changes, this change is expressed through its birth and death, similar to the bubbles in the river. On the other hand, Miyazawa, who also expressed that a human being changes, understood a human being not as an observer watching the change but as one of the many beings submerged to the change, in other words, as one of the bubbles in the river. He supported the idea that a human being was changeable just like any other thing or beings. There was no difference between him and others, no border in between, like in “Haru to Shura” 『春と修羅』(“Spring and the Asura”).

\footnotetext{
${ }^{6}$ Translation by Yasuhiko Moriguchi and David Jenkins
} 
Just as everything forms what is the sum in me so do all parts become the sum of everything

$$
\text { Haru to Shura }{ }^{7} \text { (Miyazawa 1991, 21) }
$$

In these lines, everything, all and the I are fused into one. Miyazawa thought that nothing exists separately from others but rather in relation to others, or even blended to a certain extent. The border between them does not mean so much; it is more important that they are in the same flow, thus, they interact with each other.

\subsection{Interaction between Human Beings and Nature}

The third feature concerns the idea of interaction between human beings and nature. Miyazawa was a pious Buddhist and a scientist at the same time. $\mathrm{He}$ believed that all things change constantly, as seen in the previous section, but he did not resign himself from the changeable world as the author of Hōjōki Miyazawa believed to be able to do a good deed even if it would be against nature, as both human beings and nature are changing phenomena in the same flow toward "the true happiness." He according to Nichiren believed that all things are related to each other in this process of changes, and therefore, they interact with each other. As a scientist, he devoted his life to improve rice production in Japan. In one of his works Miyazawa expressed that Budori and his colleagues believed in the change caused by the volcanic eruption, which would bring an end to a tragic situation and better life for the small farmer. For both, Miyazawa and Budori, cold weather was not supposed to be a reason for grief but something to facilitate change through the changing interaction among human beings.

Through “Kenjū Kōenrin” 『虔十公園林』(“Kenjū's Forest Playground”) Miyazawa introduces yet another story of interaction between human beings and nature. Kenjū was a boy who was rather unintelligent so he used to be laughed at by everyone in the village. One day he thought of a good idea, namely, to plant many cedars in one place, but he was laughed at again with an explanation that no cedars would grow in such a solid ground. Though it turned out true that they did not grow well, the place became a wonderful playground for children. Many years later when the village became a town, the children grew up, and Kenjū was already dead. A great doctor came back to the place. The place reminded him of

\footnotetext{
7. Translation by Roger Pulvers (Miyazawa 1996).
} 
his delightful childhood and he proposed to change it into a park. People who used to play there as children, helped him by donating money. The park was built for everyone to rest and relax.

Kenjū did not rescue people in the village in the same way that Budori was sacrificed his life to make the volcano erupt. However, the interaction between Kenjū and the cedar forest shows that they could change each other by influencing each other; Kenjū planted cedars, which gathered children in the village. When these children grew up, they protected the place of cedars in the way that the cedar forest could continue healing people. Thus, people and the cedar forest interacted with each other. They changed themselves and each other as the time passed and together they moved toward "the true happiness." Though unintelligent, Kenjū caused a change for the better. The doctor in the story said:

I guess you really can't tell who is smart and who isn't. The Buddha surely works in mysterious ways.

Kenjūkōenrin $^{8}$ (Miyazawa 1988b, 183)

Looking locally and within a short time frame, no one knows exactly what is for the better. Kenjū tells us that what someone does with a pure wish surely brings "the true happiness" as a result.

\section{Miyazawa's Literature and Contemporary Japan}

This chapter shifts the view from the age of Miyazawa to the present world. The status of present-day Japan resembles the one in which Kenji lived during economic difficulties and great disaster. Japan encountered the period of deadlock. Japan's bubble economy came to an end in the 1990s and the era of great depression set in. In addition, a global recession took hold in 2008, which gave another blow to the Japanese economy. The unemployment rate is rising, and a steady job is difficult to find, especially for the younger generation. Crimes that target simple citizens in a stressful society often threaten us. It was in 2011 that the Great East Japan Earthquake occurred and catastrophically devastated Japan. On the other hand, environmental problems and resource depletion need urgent worldwide solutions. The time has come to seize every issue globally and foresightedly.

\footnotetext{
${ }^{8}$ Translation by the author of the article.
} 
Three features in Miyazawa's literature, discussed in the previous sections, seem to suggest a way to live in the present situation. They suggest that all people should try to dress issues regarding "the true happiness" for all things. Miyazawa showed us that hope is one of the words for "true happiness" and that we are on the right path to reaching it. If this is the right direction, people should act courageously. All phenomena are changing, and their own dynamic powers cause interactions with other things. After the earthquake in 2011, many people have worked, and are still working as volunteers. Miyazawa's messages support such people and assure them that they are going in right direction.

Below is another example which carries Miyazawa's message. It is from "Ame nimo Makezu”『雨二モ負ケズ』(“Strong in the Rain”).

If there is a sick child in the east

He goes there to nurse the child

If there's a tired mother in the west

He goes to her and carries her sheaves

If someone is near death in the south

He goes and says, "Don't be afraid"

If there are strife and lawsuits in the north

He demands that the people put an end to their pettiness

He weeps at the time of drought

He plods about at a loss during the cold summer

Everyone calls him Blockhead

No one sings his praises

Or takes him to heart ...

That is the kind of person

I want to be

Amenimo Makezu9 (Miyazawa 1991, 361-62)

“Ame nimo Makezu”『雨ニモ負ケズ』(“Strong in the Rain”) is a famous poem by Miyazawa and has often been re in public places after the Great Earthquake in 2011. It provides moral support to everyone who, in any way, was affected by the power of nature in any way.

The message is very clear; what one needs to do is a small thing. This small thing is a great deed for others if only one believes in it. For that, one should

\footnotetext{
${ }^{9}$ Translation by Roger Pulvers (Miyazawa 1997).
} 
expect no recognition. Only in such a way, the good deed would bring everyone "the true happiness."

\section{Conclusion}

It is amazing that Miyazawa's literature is still at peak even more than 100 years after his birth. Miyazawa, from his scientist's perspective, sometimes used the phrase "the Cenozoic alluvial epoch" to stand for the present time. His thoughts were oriented towards the whole time span of the universe; from its formation 13 billion years ago and all the way into the future. By naming something a "good deed" he meant it as good in the flow of time. When he talked about "the true happiness," he did not mean the momentary pleasures, as was often done in the era of the bubble economy.

The verse cited below is a part of “Eiketsu no Asa”『永訣の朝』(“The Morning of Last Farewell"), a poem that Miyazawa dedicated to his dearest sister.

I now will pray with all my heart

That the snow you will eat from these two bowls

Will be transformed into heaven's ice-cream

And be offered to you and everyone as material that will be holy

On this wish I stake my very happiness.

$$
\text { Eiketsu no Asa }{ }^{10} \text { (Miyazawa 1991, 90) }
$$

His wish for everyone to pray for "the true happiness" goes beyond any borders and is one of his deepest thoughts that is very much alive in the present day.

\section{References}

Chiba, Kazumiki 千葉一幹. 2007. “Miyazawa Kenji ga Ikita Jidai 宮澤賢治が生きた時 代 (“Kenji Miyazawa and His Time”). Takushoku Daigaku Ronshū. Jinbun Shizen Ningenkagaku Kenkyū 17: 194-86.

Kamono, Chōmei. 1996. Hōjōki: Visions of a Torn World, translation by Yasuhiko Moriguchi and David Jenkins. California: Stone Bridge Press.

\footnotetext{
${ }^{10}$ Translation by Roger Pulvers (Miyazawa 1997).
} 
Kumata, Kenji 熊田健二. 1994. “Miyazawa Kenji no shūkyōteki sekai: Hokkekyōteki sekai to Ihatōbu” 宮澤賢治の宗教的世界 : 法華経的世界とイーハトーブ ("Miyazawa Kenji and his Religious World - the World of Lotus Sutra and Ihatov"). Artes liberales 55: 1-20, Iwate University.

Kurihara, Atsushi 栗原敦. 2011. “Miyazawa Kenji no bukkyō towa dono yōna mono de attaka (jō): ‘Hokkekyō’ tono Deai made” 宮沢賢治の仏教とはどのようなものであ ったか (上):「法華経」との出会いまで ("What Sort of Buddhism did Kenji Miyazawa Practice? (Vol. 1): Before He Encountered the Lotus Sutra"). Jissen kokubungaku 80: 85-100. Jissen Women's University.

Menda, Masaru 免田賢. 2012. “Miyazawa Kenji no sekai no shinrigakuteki kōsatsu” 宮沢 賢治の世界の心理学的考察 (“The Psychological World of Kenji Miyazawa”). Kyōikugakubu ronshū 23: 147-63. Bukkyō University.

Nakano, Shinji 中野新治. 1984. “Miyazawa Kenji ni okeru 'Dōwa'no seiritsu - Kitei to shite no Hokke Shinkō” 宮澤賢治に於ける「童話」の成立一基底としての法華信 仰— ("Formation of 'Children's Stories' in Miyazawa Kenji - Faith in Lotus Sutra as a base”). Nihon Bungaku Kenkyū 20: 163-74. Baikō Gakuin University.

Numata, Ken’ya 沼田健哉. 1997. “Miyazawa Kenji ni okeru Kagaku to Shūkyō” 宮沢賢 治における科学と宗教 (“Science and Religion in the Literature of Kenji Miyazawa”). Sōgō kenkyūsho Kiyō 22 (3): 83-96. St. Andrew’s University.

Okaya, Akio 岡屋昭雄. 1996. “Miyazawa Kenji Ron: Miyazawa Kenji no Shūkyōteki Uchū ni tsuite” 宮澤賢治論：宮澤賢治の宗教的宇宙について(“On Essay of Kenji Miyazawa"). Kyōikugakubu Ronshū 7: 1-19. Bukkyō University.

Okaya, Akio 岡屋昭雄. 1999. “Miyazawa Kenji Ron: Nichijō to Hi-nichijō no Uchū” 宮 澤賢治論：日常と非日常の宇宙 (“On Essay of Kenji Miyazawa: Research Notes”). Kyōikugakubu Ronsh̄̄ 7: 1-19. Bukkyō University.

Sueki, Fumihiko 末木文美士. 2000. Nichiren Nyūmon - Gensei o Utsu Shisō 日蓮入門— 一現世を撃つ思想 (Introduction to Nichiren - A Tought That Attacks the Present Society). Tōkyō: Chikuma Shinsho.

Tanikawa, Tetsuzō 谷川徹三. 1950. Daiyojigen no geijutsu: Miyazawa Kenji-Daisanron 第四次元の藝術 : 宮澤賢治第三論 (The Art in the Four Dimension: the Third Discussion on Miyazawa Kenji). Tōkyō: Kōbundō.

Tanikawa, Tetsuzō 谷川徹三. 1951. Miyazawa Kenji 宮沢賢治 (Miyazawa Kenji). Tōkyō: Kaname shobō.

Tanikawa, Tetsuzō 谷川徹三. 1953. Miyazawa Kenji no sekai 宮沢賢治の世界 (The World of Miyazawa Kenji). Tōkyō: Hōsei daigaku shuppankyoku.

Umehara, Takeshi 梅原猛. 1985. Kenji no Uchū 賢治の宇宙 (The World of Kenji). Tōkyō: Kōsei shuppansha. 
Yamaori, Tetsuo 山折哲雄. 2006. “Miyazawa Kenji no Uchū” 宮澤賢治の宇宙 (“Miyazawa’s Spiritual Cosmos”). Kokusai Bunka Ronshū 34: 99-130. St. Andrew’s University.

Yoshimoto, Takaaki 吉本隆明. 1989. Miyazawa Kenji 宮沢賢治 (Miyazawa Kenji). Tōkyō: Chikuma shobō.

Yoshimura, Akira 吉村昭. 2004. Sanriku Kaigan Ōtsunami 三陸海岸大津波 (Sanriku Offshore Great Tsunami). Tōkyō: Bungei Shunjū.

\section{Literatures}

Miyazawa, Kenji 宮澤賢治. 1988a. Shinpen Ginga Tetsudō no Yoru 新編 銀河鉄道の夜 (New Edition: Night on the Milky Way Train). Tōkyō: Shinchō Bunko.

Miyazawa, Kenji 宮澤賢治. 1988b. Shinpen Kaze no Matasaburō 新編 風の又三郎 (New Edition - Matasaburō, the Wind Imp). Tōkyō: Shinchō Bunko.

Miyazawa, Kenji 宮澤賢治. 1991. Shinpen Miyazawa Kenji Shihsū 新編 宮澤賢治詩集 (New Edition -The Collected Poems of Miyazawa Kenji). Tōkyō: Shinchō Bunko.

Miyazawa, Kenji 宮澤賢治. 1997. Eigo de Yomu Miyazawa Kenji Shishū 英語で読む宮 沢賢治詩集 (Reing in English: The Collected Poems of Miyazawa Kenji, Roger Pulvers Translations). Tōkyō: Chikuma Bunko.

\section{Website}

National Agriculture and Food Research Organization, "Rice Growing and Low Summer Temperatures in the Tōhoku Region ”. Accessed March 30, 2013, http://www.reigai.affrc.go.jp/zusetu/inasaku/jittai/syuryotokei.pdf. 